\title{
Flexible budgeting under time-driven activity based cost as a tool in management accounting: Application in educational institution
}

\author{
Hamide Ozyürek $^{1,} *$, Yakup Ulutürk ${ }^{2}$ \\ Turgut Ozal University, Ankara, Turkey
}

\section{Keywords:}

Time driven activity-based

Budgeting

Flexible budget

Strategic management

Accounting

Received: 10 March 2016

Accepted: 15 March 2016

Published: 26 April 2016

\begin{abstract}
The rapidly changing competitive conditions, economic and technological developments have brought the diversity of firm's products and services. One-kind products and services were replaced by the production of a wide range of products and services. International firms are seeing that increased demand has led to different product markets. All these developments have also led to the international level of competition and made necessary to conduct new researches on management accounting with emphasis on planning, controlling and auditing. In this study, time and activity based flexible budget application is made by looking at a new approach to the budgeting process, which is one of the most important tools of planning. Purpose of this study is to show that time driven activity based costing system for education sector can be considered in the calculation of the costs and performance of the steps of taking advantage of future budget planning in education sector. For this purpose, time driven activity based budgeting was implemented in primary schools and kindergartens in Ankara operating within a private educational institution. The result of the study, in order to prepare a flexible budget depending on time, must have qualified persons and the need for cooperation of all employees in the implementation. During the calculation of the costs, to reach more accurate results due to consideration of idle capacity, findings show the benefits provide for large corporations having complex structure. This also proves that every customer is not profitable.
\end{abstract}

(C) 2016 The Author(s). Published by TAF Publishing.

\section{INTRODUCTION}

Strategic cost management and management accounting have begun to change traditional practices, the neglected external environment in recent years has started to be taken into account. Quality analysis of the most important changes, target costing, outsourcing, issues related to

*Corresponding author: Hamide Ozyürek

E-mail: hozyurek@turgutozal.edu.tr natural and external environment, constraints and job volume analysis, competitive analysis, product life cycle analysis, intellectual capital analysis, benchmarking applications, value chain analysis, change engineering and activity-based management/costing seems to be in practice (Edwards, 2000). Activity-based costing strategic methods eliminating non- value added activities. Managerial responsibilities and processes such as 
customer field add enough flexibility in the analysis of costs except for products objects. ERP (Enterprise Resource Planning) and CRM (Customer Relationship Management) allow the reception of data by providing integration with systems (Kaplan \& Steven, 2004:15-16). Activity-based management/cost system as part of a continuous improvement program to maximize the level of the potential for strategic planning must be integrated with budgeting, capacity management, life cycle management, management of limitations, time -based management, restructuring of business processes, total quality management and total preventive maintenance (Edwards, 2000). Therefore, activity-based budgeting approach focuses on creating budget based model on the contrary of traditional product market. Kaplan \& Norton (2008) pioneered by ABC (Activity-based cost) model is used to create the budget on behalf of management to obtain accurate and predictable budget estimates.

Activity-based as a result of budgeting encourages the allocation of resources to those used in the best possible way in accordance with organizational priorities, reduce the scope of the political game, increases success in decision-making and performance assessment and provides operational flexibility (Kaplan \& Norton, 2008). Using the ABC method on the budget study also concluded that managers have to influence the behavior of the positive and lead to a reduction in non- value added workrelated behavior by allowing them to be more careful (Bruggeman \& Waeytens, 1995). TDABC (Time Driven Activity-Based Cost) method is used in environments where traditional budgeting process would not be correct and this method has been applied to the budgeting system and its achievements have been obtained TDABB (Time Driven Activity-Based Budgeting) process with cost information obtained in step provides the estimates of future successfully. The main objective of this study by using costs, activity analysis and other data was obtained from TDABC in order to implement the process of TDABB in an educational institution. The questions considered to be answered as a result of this application are as follows; -Is it TDABC implemented in educational institutions? -Is it TDABC applied to identify non- value added activities as a result?

-A different result appeared the in costs obtained by the traditional system?

-What are the reasons if differences occur?

-Can TDABB process according to the obtained data be performed successfully?

-How TDABB has impact on the profitability and performance measurement?

-How does TDABB provide data on capacity utilization?

\section{LITERATURE REVIEW}

In recent years, studies based on time-driven activitybased costing have been done using the budget implementation. (Pernot, Roodhooft \& Van den Abbeele, 2007) have carried out practice in a university library and on the basis of the obtained data, reduced costs and improved the quality of library services based on a study of TDABC that had reached the result considered very useful. Executives expressed the proposal would work for the implementation of other libraries in the adoption and application of this as a gain. Saban \& Irak (2009) with an example of the application of time driven activity-based costing system in the detection of non- economic value added activities and taking measures have focused on increasing profitability considerations. Also the system gives accurate and timely information to administrator to decide, offers cost and profitability information faster and more cheaply. One of the biggest benefits for management to spend more time for the right products to provide focus on customers bringing more profit.

Hoozée \& Bruggeman (2010) emphasized that the attitude of the government in implementing the new system is important, the autocratic management system would be difficult to apply this application. They emphasized the importance of management in the success of the application. The success of the system will be increased when more people will contribute to the new system that will be stated by the supportive management of the application. (Demeere, Stouthuysen \& Roodhooft, 2010) have carried out their work in the health sector applications. TDABC system is an important model to obtain accurate and reliable information and stressed the importance of providing clear communication between different departments. Some of the results of the implementation are improvement of the operational tasks, the lack of communication between doctors and managers being reduced and increased productivity so that the findings were obtained in the institution. Cengiz (2011) worked on the difference between activity-based costing (ABC) and time-driven activity-based costing (TDABC) that were applied as a case study in a furniture manufacturer company. In the case study, the biggest difference between the $\mathrm{ABC}$ application and TDABC application stated that the $A B C$ ignored the calculation of the cost of idle capacity. Polat (2011) has applied the TDABC system in an industrial business. The application results; TDABC's cost 
calculation method as compared to traditional $\mathrm{ABC}$, products that make a difference in some of the idle capacity has been said to be the most important reason of this notice. As a result of the application made to the business managers the future process of improvement and product pricing decisions, $\mathrm{ABC}$ will produce meaningful information but exemplary business, TDABC would be particularly favorable to use because of the clarity brought to idle capacity issues observed. Hajiha \& Alishah (2011) has carried out his application work in a hotel operating in Iran. According to the results obtained in order to increase efficiency and improve the processes proposed model allows managers to develop strategy. The cost of the idle resources is not suitable for analyzing customer profitability reached by the finding that the current cost system ignored. Metin \& Coskun (2012) have explained activity-based budgeting systems in their study. $\mathrm{ABC}$ increaed the degree of accuracy of financial forecasts, resources, activities and developments in the understanding of the administrative costs of putting forward the relationship in a very open manner; They revealed the cost of providing measuring and managing performance.

Terungwa (2012) in his work, conducted a profitability analysis at the medium size restaurant in Nigeria. As a result, he has highlighted that time was a very important resource in the services business and calculation of service in TDABC application based on use of cost and time has stressed a better cost system for small service business of TDABC application. Özyürek \& Dinç (2014) undertook the TDABC applications in medical device manufacturer companies operating in Ankara. According to results every product is not profitable product and every customer is not profitable customer as found. Even managers were found to be unaware that some products are sold at a loss. By using TDABC to determine the use of the system capacity it has been found that only operation at full capacity in the procurement department should be pursued. In other sections idle capacity is seen. In the literature, activity-based flexible time-based budgeting was not observed in educational institutions. Therefore, it is considered to fill this gap in the literature for this study.

\section{METHODOLOGY}

The purpose of the study, by using the case study method was to implement TDABB method in an educational institution and to answer their research questions. 2015 data were used in the TDABB study because it is important for the accuracy of the model using data for the most recent year. Kaplan \& Anderson, (2007:87).The numeric data of the educational institutions carried out practice was obtained from managers, teachers, interviews with employees, observations of the activities and the accounting data system. In the literature, the steps to be performed to create a TDABB model has been identify that are as follows (Kaplan \& Anderson, 2007:87)

1. TDABC model must be created by utilizing the latest data.

2. Products, services and customer profitability should be calculated.

3. Administrative decisions must be taken for the development of the company's future.

4. The company's production and sales forecasts for the following period should be determined.

5. The demand for the resource capacity to meet the needs of the future forecast period should be established.

6. It should consist of the costs necessary to determine how to provide resources capacity in the future.

Taking into account budgeting stage in the literature, this study was performed in the following order in the educational institutions. In the implementation phase of the system, first the meeting was organized with administrators of the institutions in order to explain the system and take the support of the management. Process in educational institutions (activity pool) was determined. Activities to be performed for each sub-process the amount of time drivers and also time for these activities were found with those involved in these activities. Then the amount of time drivers had been distributed in accordance with the student group consuming this time. Each sub-process operations occurred on the basis of equations formed and then the total requested time periods for each activity were calculated by subtracting holidays in detail. Then, a total amount of practical capacity of the staff involved in this process had been calculated considering the holidays. The idle capacity of each activity was calculated by taking difference between the requested time for the implementation of activities and time capacity of the employees related with these activities. Then, capacity cost ratios were calculated by dividing costs of processes that occurred in the distribution result with the total time of the practical capacity of the employees. Each group costs were calculated by multiplying the time requested for each group and created capacity cost ratio. Idle costs had been calculated by taking 1 . distribution costs resulting from the difference of the total cost corresponding to the requested 
time. The findings of the above-mentioned process are described in the next section.

\section{INSTALLING TDABC MODEL Identifying Activities}

In the time-driven activity based costing study, the functioning of the business process should be well understood and company-owned operations analysis must be correctly identified. It is possible to encounter a lot of activities during activity analysis. Therefore processes and sub-processes of these processes should be classified correctly. Then to determine the amount of time requested for the accomplishment of activity on the sub-process will be easier. Organization that was created with 13 different processes ( A-1 registration,A-2 Preparation Training, A-3 Education Season, A-4 TEOG, A-5 Socials Act.\& Clubs, etc...) was conducted in the institution where the application was carried out. In this study, only the A-1 registration process which is one of the 13 processes and its stages is shown in the figure 1.

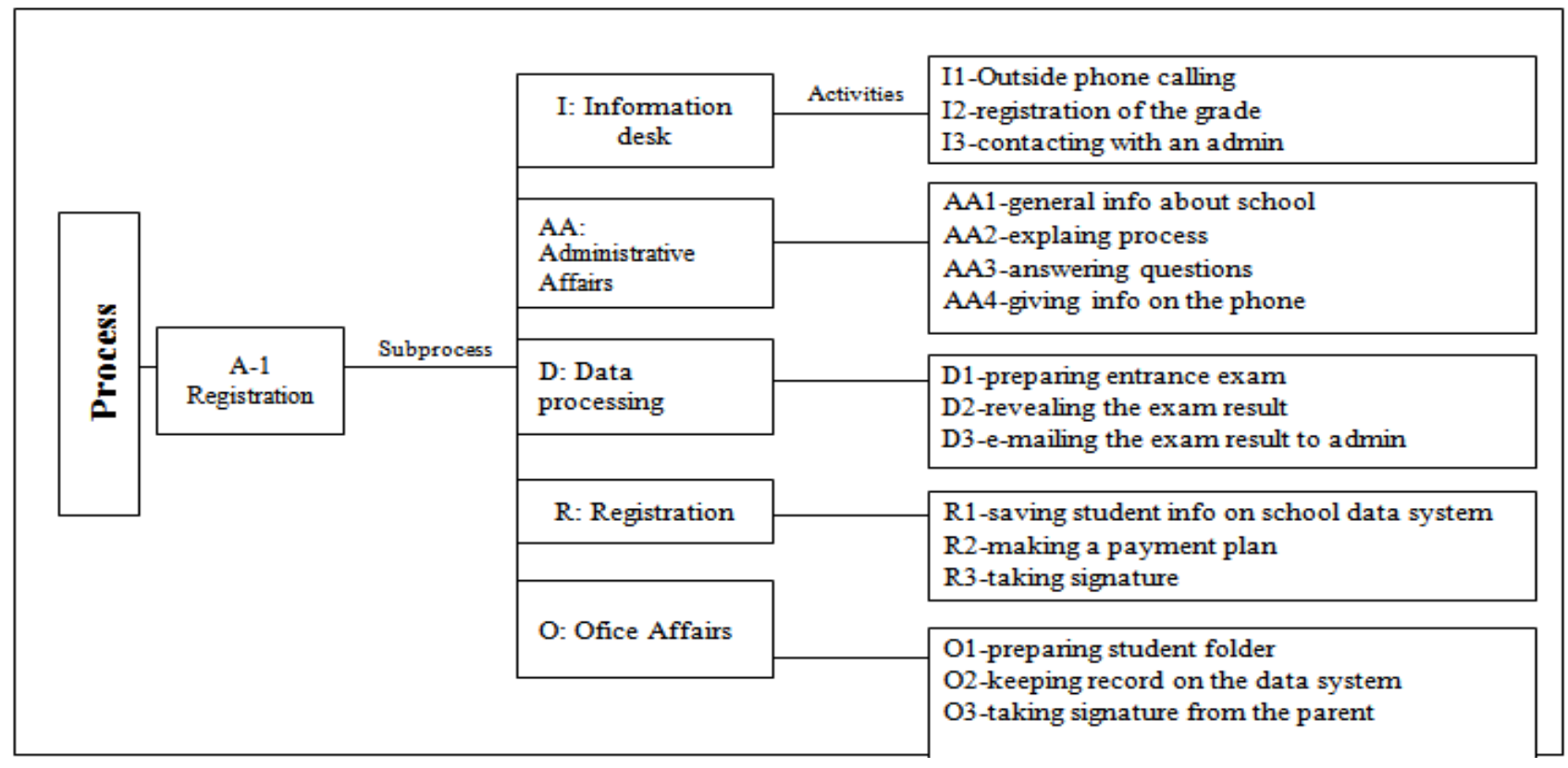

FIGURE 1. Process and operations for registration department

TABLE 1. Cost drivers for first distribution

\section{Service Production Expenses}

Food and Catering Expenses

Education Training Tools Expenses

Workers' Salaries

Heating, Lighting and Water Expenses

Communication \& Other Services Exp.

Cleaning and Pest Control Costs

Security Costs

\section{Cost Drivers}

Direct A8

Direct related services A1, A2, A3, A4, A5, A6, A10,

Direct transferred to all activities

Area $\left(\mathrm{m}^{2}\right)$

Direct transferred to all activities

Area $\left(\mathrm{m}^{2}\right)$

Direct A11 
Table 2 shows some expenses derived from the institution's income statement (source) and 1.Distribution of cost drivers. This information has been obtained in person interviews with school management and accounting department. First distribution is made by utilizing the information in this table.

TABLE 2. Registration process and time per transaction

\begin{tabular}{|c|c|c|c|c|c|}
\hline \multirow{17}{*}{ Process } & Subprocess & Activities & Time Drivers & $\begin{array}{l}\text { Amount of Time Driver } \\
3500\end{array}$ & $\begin{array}{l}\text { TimePer } \\
\text { Transactio }\end{array}$ \\
\hline & I & I1 & The number of calls made & & ${ }^{-} 5$ \\
\hline & & $\mathrm{I} 2$ & New Student & 740 & 5 \\
\hline & & I3 & New Student & 740 & 5 \\
\hline & & AA1 & New Student & 740 & 30 \\
\hline & & AA2 & New Student & 740 & 15 \\
\hline & & AA3 & New Student & 740 & 20 \\
\hline & AA & AA4 & The number of calls made & 3500 & 15 \\
\hline & & D1 & New Student & 740 & 20 \\
\hline & & D2 & New Student & 740 & 10 \\
\hline & $\mathrm{D}$ & D3 & New Student & 740 & 10 \\
\hline & & $\mathrm{R} 1$ & New Student & 740 & 15 \\
\hline & & $\mathrm{R} 2$ & New and Old Students & 1867 & 15 \\
\hline & $\mathrm{R}$ & R3 & New and Old Students & 1867 & 10 \\
\hline & & 01 & New Student & 740 & 15 \\
\hline & & 02 & New Student & 740 & 10 \\
\hline & 0 & 03 & New and Old Students & 1867 & 15 \\
\hline
\end{tabular}

The first distribution was conducted after identified activities and activity pools, creating cost drivers and cost drivers of their units to be used. After costs of each activity were collected in the activity pool, sub-processes, operations time drivers and process time per transaction were identified. Time equations are formed. Time Equation for Information Desk3 different activities that occur in the information deskare as follows: "Out side phone calling", "registration of the grade", "contacting with an admin". The activities in this section lasts for 15 minutes in total.

Time equation for information desk: $5 * \mathrm{X} 1+5 * \mathrm{X} 2+5 * \mathrm{X} 3$

$\mathrm{X} 1=$ The number of calls made

$\mathrm{X} 2$ and $\mathrm{X} 3=$ New student numbers

\section{Time Equation for Administrative Affairs}

Activities that occur in the administrative affairs are as follows: "giving general info about school", "explaing process"," answering parent's questions ", "giving info on the phone" 80 minutes in the total time required for these activities. Time equation for administrative affairs: $30 * \mathrm{X} 1+15 * \mathrm{X} 2+20 * \mathrm{X} 3+15 * \mathrm{X} 4$

$\mathrm{X} 1, \mathrm{X} 2 \mathrm{veX} 3=$ New student numbers

$\mathrm{X} 4=$ the number of calls made

\section{Time Equation for Data Processing}

Activities that occur in the data processing are as follows: "preparing entrance exam", "revealing the exam result"," emailing the exam result to admin" 40 minutes is total time required for these activities

Time equation for data processing $=20 * \mathrm{X} 1+10 * \mathrm{X} 2+10 * \mathrm{X} 3$

$\mathrm{X} 1, \mathrm{X} 2$, and $\mathrm{X} 3=$ New student numbers

\section{Time Equation for Registration}

Activities that occur in the registration are as follows : "saving student info on school data system"," making a payment plan"," taking signature". The activities in this section lasts for 40 minutes in total.

Time equation for registration $=15^{*} \mathrm{X} 1+15^{*} \mathrm{X} 2+10^{*} \mathrm{X} 3$

$\mathrm{X} 1=$ New student numbers,

$\mathrm{X} 2$ and X3 =New and Old Students

\section{Time Equation for Office Affairs}

Activities that occur in the office affairs are as follows :"preparing student folder"," keeping record on the data system", "taking signature from the parent ".The total time is 40 minutes spent in such activities. Time equation for office affairs $=15 * \mathrm{X} 1+10 * \mathrm{X} 2+15 * \mathrm{X} 3$

$\mathrm{X} 1=$ New student numbers 
$\mathrm{X} 2=$ New student numbers

X3 $=$ New and Old Students
After determining the amount of time drivers, requested time for each stage group is calculated using time equations.

Table 3. Requested times of registration department calculated by time equations

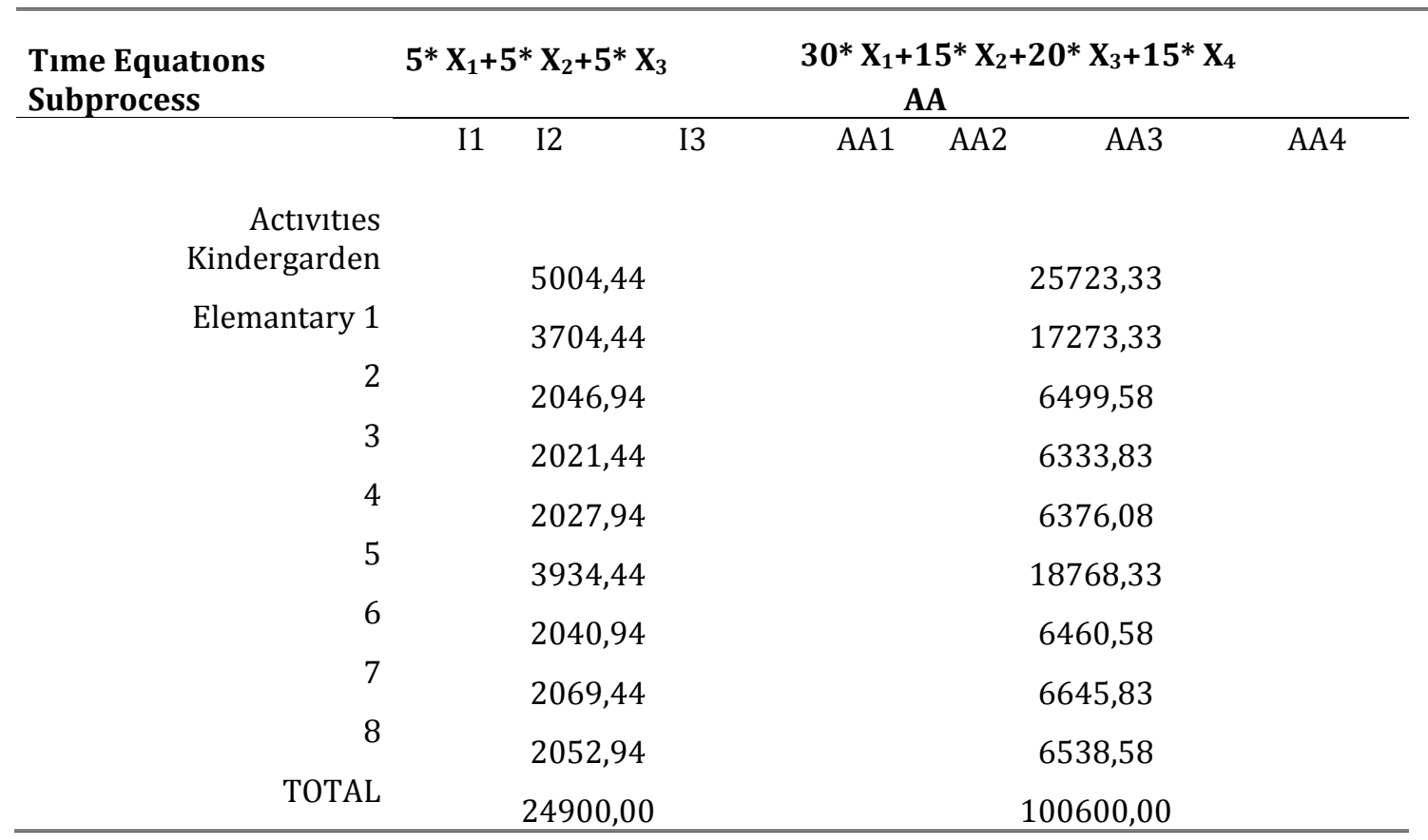

Implementations of this part of the capacity cost ratio were calculated. Then by multiplying the requested time with capacity cost ratio for each section, the costs for the requested period were calculated for each section. Finally, the unit cost for each student was determined. After this stage, flexible budgeting systems carried out based on the Flexible budgeting steps were carried out as follows.

1. After the TDABC application, the budgeting process has started. It was decided in consultation with administrators of the institutions working on establishing two different scenarios for the next year's flexible budget estimates.

2. The estimates of the number of students for the next term are determined.

3. The identification of resources is determined to meet the needs of the future period forecast.

4. How to create the necessary costs is determined according to both scenarios to supply in the coming period capacity.

\section{CONCLUSION}

Traditional methods are used in educational institutions where the study was conducted. The installation of the
TDABC system was carried out after consultation with administrators. Comparing both results showed that there are differences. TDABC system has reached the conclusion that administrators need to decide the correct calculation of the cost, non-value added production activities determined, idle capacity be taken into account. In the educational institutions that carried out TDABC practice a fixed price policy is implemented for all students. However, certain activities which benefit only from the students in a particular class the other class of students don't use these activities. Therefore, student costs in the traditional method of fixed which is composed of different TDABC systems are considered. After the application, administrators have decided to reconsider the price policy applied to all classes of education. In addition, studies have demonstrated that TDABC process contributed significantly to the strategic and operational aspects. It has been possible to identify common objectives due to the involvement of all employees in the TDABB process. It allows a capacity analysis provided for removal of the unused idle capacity. It has been calculated that the TDABB process can be successfully implemented in educational institutions. 


\section{REFERENCES}

Bruggeman W., \& Waeytens D. 1995. The impact of ABM systems on information asymmetry, budget slack creation and other dysfunctional behaviors: A Lab Experiment. Paper presented at the 2nd International Manufacturing Accounting Seminar, Brugge, Belgium.

Cengiz, E. 2011. Faaliyet tabanlı maliyetleme ve sürece dayalı faaliyet tabanlı maliyetleme arasındaki farklar-bir mobilya üreticisi firmadavaka çalısması. Muhasebe ve Finansman Dergisi Nisan, 2(1): 33-58.

Demeere, N., Stouthuysen, K., \& Roodhooft, F. 2009. Time-driven activity-based costing in an outpatient clinic environment: Development, relevance and managerial impact. Health policy, 92(2): 296-304. DoI: 10.1016/j.healthpol.2009.05.003

Edwards., J.B. 2000. The new cost management culture: Where are we going? Journal of Corporate Accounting \& Finance, 11(3): 3-8. DOI: 10.1002/1097-0053(200003/04)

Hajiha, Z., \& Alishah, S.S. 2011. Implementation of time-driven activity-based costing system and customer profitability analysis in the hospitality industry: Evidence from Iran. Economics and Finance Review, 1(8): 57-67.

Hoozée, S., \& Bruggeman, W. 2010. Identifying operational improvements during the design process of a time-driven ABC system: The role of collective worker participation and leadership style. Management Accounting Research, 21(3): 185-198. DOI: 10.1016/j.mar.2010.01.003

Kaplan R.S., \& Norton D. 2008. The execution premium. Cambridge, MA: Harvard Business School Press.

Kaplan, R.S., \& Anderson, S.R. 2007. Time-driven acitivity-based costing: A simpler and more powerful path to higher profits. European Accounting Review, 16(4): 855-866.

Kaplan, R.S., \& Steven R.A. 2004. Time-driven activity-based costing. Harvard Business Review, 82(11): $131-138$.

Metin, Y., \& Coşkun, A. 2012. Ortaöğretim kurumlarında öğrenci birim maliyetlerinin hesaplanmasında modern bir yöntem. Dumlupınar Üniversitesi Sosyal Bilimler Enstitüsü Dergisi, 33(33): 277-290.

Özyürek, H., \& Dinç, Y. 2014. Son yıllarda maliyet dağitiminda kullanilan yöntemler ve zamana dayali faaliyet tabanli maliyetleme olay çalişmasi. C.Ü. İktisadi ve Ídari Bilimler Dergisi, 15(1): 345-364.

Pernot, E., Roodhooft, F., \& Van den Abbeele, A. 2007. Time-driven activity-based costing for inter-library services: A case study in a university. The Journal of Academic Librarianship, 33(5): 551-560. D0I: 10.1016/j.acalib.2007.06.001

Polat, L. 2011. Zaman sürücülü faaliyet tabanlı maliyetlemenin bir sanayi đşletmesinde uygulanması. Muhasebe Ve Finansman Dergisi, 4(49): 127-137.

Saban, M., \& İrak, G.G. 2009. Cağdaş maliyet yönetimi sistemlerinden sürece dayali faaliyet tabanli maliyetleme zonguldak karaelmas university. Journal of Social Sciences, 5(10): 97-108.

Terungwa, A. 2012. Practicability of time-driven activity-based costing on profitability of restaurants in makurdi metropolis of benue state, Nigeria. Journal of Contemporary Management Submitted, 1(2): 33-44.

— This article does not have any appendix. - 